\title{
PERENCANAAN ULANG (REDESIGN) PEMBANGUNAN RUANG BELAJAR SMK AL- MURQONIYAH, HAMBALANG
}

\author{
*Era Agita Kabdiyono', Riesa Syariful Akbar ${ }^{2}$ \\ ${ }^{1,2}$ Fakultas Teknik dan Informatika, Program Studi Teknik Sipil, Universitas Dian Nusantara, Jakarta, Indonesia
}

*Email Korespondensi:

era.agita.k@undira.ac.id

\section{ARTIKEL INFORMASI}

Diterima:

15 March 2021

Direvisi:

20 April 2021

Dipublikasi:

16 Mei 2021

\begin{abstract}
ABSTRAK
Sekolah merupakan sarana penting dalam meningkatkan kehidupan dan kualitas hidup manusia tertutama dalam mutu pendidikan anak bangsa. Di dalamnya, terdapat kegiatan belajar dan mengajar bagi para siswa/siswi oleh guru-guru di sekolah. Tujuan penelitian pada laporan ini adalah merencanakan ulang (redesign) struktur bangunan gedung sekolah SMK Al-Murqoniyah dengan menggunakan SNI gempa SNI 1726 - 2012 dan SNI beton SNI 2847 - 2013. Direncanakan struktur gedung bertingkat 2 lantai dengan menggunakan metode sistem rangka pemikul momen dengan pemodelan struktur menggunakan portal 3 dimensi dengan bantuan program ETABS versi 2013. Gedung SMK Al - Murqoniyah didesain dengan struktur beton bertulang. Jumlah tulangan yang didapatkan dari hasil analisis untuk tulangan pelat $(\mathrm{t}=120 \mathrm{~mm})$ digunakan tulangan $\mathrm{D} 10-100$ untuk masingmasing tumpuan dan lapangan, pada struktur balok (200X400 $\mathrm{mm})$ digunakan tulangan lentur 3D13 pada daerah tekan dan 3D13 pada daerah tarik, dengan jarak sengkang pada tumpuan adalah D10-100 pada daerah tumpuan dan D10-150 pada daerah lapangan, serta untuk tulangan lentur kolom (200X250 mm) digunakan tulangan 10D16 dan tulangan sengkang D10-100 pada daerah tumpuan dan tulangan D10-150 pada daerah lapangan. Berdasarkan hasil analisis yang telah dilakukan menggunakan bantuan program analisis struktur, dapat dinyatakan bahwa elemen struktur gedung ini aman secara analisis dan struktur gedung belajar SMK Al- Murqoniyah telah direncanakan sesuai kaidah perancangan yang berlaku.
\end{abstract}

Keywords: Struktur Beton Bertulang, Redesign, Analisis Tulangan

\section{PENDAHULUAN}

Sekolah merupakan sarana penting dalam meningkatkan kehidupan dan kualitas hidup manusia tertutama dalam mutu pendidikan anak bangsa. Di dalamnya, terdapat kegiatan belajar dan mengajar bagi para siswa/siswi oleh guru-guru di sekolah. Salah satu faktor penunjang pembelajaran di sekolah adalah ruang untuk belajar dan serangkaian kegiatan. Sekolah SMK Al-Murqoniyah adalah sekolah menengah kejuruan swasta yang terletak di Kabupaten Bogor. Seiring dengan kebutuhan ruang belajar yang sesuai dengan kapasitas siswa/siswi setiap tahunya, maka direncakan adanya penambahan ruang kelas baru. Untuk itu, dibutuhkan analisis perhitungan struktur gedung sekolah yang baru guna menunjang kegiatan pembelajaran di sekolah SMK Al-Murqoniyah. Sekolah ini sebelumnya sudah memiliki struktur exsting 1 lantai yang sudah 
digunakan dalam kegiatan belajar mengajar. Seiring bertambahnya waktu dan calon siswa baru, penambahan ruang kelas baru untuk proses dalam belajar mengajar akan sangat membantu akademik dalam menampung siswa/i dengan jumlah yang semakin bertambah, dengan begitu berbagai macam materi dapat disampaikan oleh guru saat berada di dalam kelas. Dengan penambahan ruang kelas tingkat 2 lantai guna untuk menciptakan suasana belajar baru yang akan menumbuhkan minat dan menciptakan semangat belajar yang sesuai dengan kurikulum dan cara belajar yang efektif dan efisien.

Pembangunan ulang (redesign) sekolah SMK Al-Murqoniyah direncanakan akan dibangun dua lantai yang difungsikan sebagai ruang kelas, ruang guru, ruang kepala sekolah, dan ruang lab/ praktikum program keahlian teknik elektronika. Metode yang dipakai dalam pembangunannya adalah menggunakan metode konvensional dengan material beton bertulang. Berdasarkan latar belakang di atas, maka penelitian ini dilakukan untuk merancang struktur bangunan gedung sekolah SMK Al-Murqoniyah yang berjumlah 2 lantai, material utama yang digunakan adalah beton bertulang. Hasil dari penelitian ini berupa dimensi dan tulangan sesuai dengan syarat kekuatan yang di atur dalam SNI 1726 - 2012 tentang Tata Cara Perencanaan Ketahanan Gempa Untuk Bangunan Gedung dan SNI 2847 - 2013 tentang Tata Cara Perencanaan Struktur Beton Untuk Bangunan Gedung. Tujuan penelitian pada laporan ini adalah merencanakan ulang (redesign ) struktur bangunan (redesign) gedung sekolah SMK Al-Murqoniyah dengan menggunakan SNI gempa SNI 1726 - 2012 dan SNI beton SNI 2847 - 2013.

\section{KAJIAN PUSTAKA}

\section{Pembebanan Struktur}

Ketentuan mengenai perencanaan dalam tata cara SNI 2847-2013 didasarkan pada asumsi bahwa struktur direncanakan untuk memikul beban kerjanya. Berdasarkan Peraturan Pembebanan Indonesia untuk Gedung tahun 1983 pasal 1 halaman 7 menjelaskan mengenai definisi pembebanan, antara lain:

1) Beban mati (Dead Load) adalah berat semua bagian dari suatu gedung yang bersifat tetap, termasuk segala unsur tambahan, penyelesaian, serta peralatan tetap yang merupakan bagian yang tak terpisahkan dari gedung tersebut.

2) Beban hidup (Live Load) adalah semua beban yang terjadi akibat penggunaan suatu gedung dan kedalamnya termasuk beban - beban pada lantai yang berasal dari beban - beban yang dapat berpindah sehingga mengakibatkan perubahan dalam pembebanan lantai dan atap. Khusus atap, beban hidup termasuk pada beban air hujan yang diakibatkan oleh genangan air maupun butiran air yang jatuh.

3) Beban angin (Wind Load) adalah semua beban yang bekerja pada gedung atau bagian gedung yang disebabkan oleh selisih dalam tekanan udara.

4) Beban gempa (Earthquake Load) adalah semua beban static ekuivalen yang bekerja pada gedung atau bagian gedung yag menirukan pengaruh dari gerakan tanah akibat gempa tersebut. Pengaruh gempa pada struktur gedung ditentukan berdasarkan suatu analisa dinamik

\section{Kekakuan Struktur}

Menurut Wolfgang Schueller kekakuan struktur (Ir. Muji Indarwanto, 2014), rangka kaku (rigid frame) merupakan sambungan kaku digunakan antara susunan struktur linear untuk membentuk bidang vertikal dan horizontal. Bidang vertikal terdiri dari kolom dan balok, biasanya pada grid persegi.

\section{Faktor Keutamaan dan Kategori Risiko Struktur}

Pasal 4.1.2 SNI 1726 - 2012, untuk berbagai kategori risiko struktur bangunan gedung dan non gedung sesuai tabel 2.1 pengaruh gempa rencana terhadapnya harus dikalikan dengan factor keutamaan Ie. Khusus untuk struktur bangunan dengan kategori risiko IV, bila dibutuhkan pintu masuk untuk operasional dan struktur bangunan yang bersebelahan, maka struktur bangunan yang bersebelahan tersebut harus didesain sesuai dengan kategori risiko IV. 
Tabel 1. Kategori risiko bangunan gedung dan non gedung untuk beban gempa

JenisPemanfaaan

Gedung dan non gedung yang ditunjukkan sebagai fasilitas

yang penting, termasuk, tetapi tidak dibatasi untuk:

- Bangunan -bangunan monumental

- Gedung sekolah dan fasilitas pendidikan

- Rumah sakit dan fasilitas kesehatan lainnya yang

IV

memiliki fasilitas bedah dan unit gawat darurat

- Fasilitas pemadam kebakaran, ambulans, dan kantor polisi , serta garasi kendaraan darurat

Sumber : SNI $1726-2012$

\section{Perancangan Struktur Beton Bertulang}

SNI 2847-2013, beton adalah campuran antara semen portland atau semen hidraulik yang lain, agregat halus, agregat kasar dan air, dengan atau tanpa bahan tambahan yang membentuk masa padat. SNI 2847-2013, beton bertulang adalah beton yang ditulangi dengan luas dan jumlah tulangan yang tidak kurang dari nilai minimum, yang disyaratkan dengan atau tanpa prategang, dan direncanakan berdasarkan asumsi bahwa kedua material bekerja bersama-sama dalam menahan gaya yang bekerja.

\section{Analisis dan Perancangan}

\section{a. Perancangan}

Semua komponen struktur beton bertulang harus direncanakan cukup kuat sesuai dengan ketentuan yang dipersyaratkan dalam standar SNI 2847-2013 tentang tata cara perhitungan struktur beton untuk bangunan gedung, dengan menggunakan faktor beban dan faktor reduksi kekuatan $\varphi$ yang sesuai .

\section{b. Modulus Elastisitas}

Nilai modulus elastisitas beton dan baja tulangan ditentukan sebagai berikut:

1) Untuk nilai wc diantara $1500 \mathrm{~kg} / \mathrm{m} 3$ dan $2500 \mathrm{~kg} / \mathrm{m} 3$, nilai modulus elastisitas beton Ec dapat diambil sebesar (wc)1.5. 0.0043 $\sqrt{ } f^{\prime} \mathrm{c}(\mathrm{MPa})$.

2) Untuk beton normal Ec dapat diambil sebesar $4700 \sqrt{ } f^{\prime} \mathrm{c}$.

3) Modulus elastisitas untuk tulangan non-prategang Es diambil sebesar $200000 \mathrm{MPa}$.

\section{c. Ketentuan Mengenai Kekuatan dan Kemampuan Layan}

Struktur harus direncanakan hingga semua penampang mempunyai kuat rencana minimum sama dengan kuat perlu, yang dihitung berdasarkan kombinasi beban dan gaya terfaktor (Ramadhan, 2013).

\section{d. Kuat Perlu}

Kekuatan suatu komponen struktur atau penampang yang diperlukan untuk menahan beban terfaktor atau momen dan gaya dalam yang berkaitan dengan beban tersebut dalam suatu kombinasi seperti yang ditetapkan dalam tata cara SNI 2847-2013.

Kuat perlu yang dipersyaratkan dalam pasal 9.2.1 SNI 2847-2013 tersebut adalah:

$\mathrm{U}=1,4 \mathrm{D}$

$\mathrm{U}=1,2 \mathrm{D}+1,6 \mathrm{~L}$

$\mathrm{U}=0,75(1,2 . \mathrm{D}+1,6 \cdot \mathrm{L}+1,6 . \mathrm{W})$

$\mathrm{U}=0,9 . \mathrm{D}+1,3 . \mathrm{W}$

$\mathrm{U}=1,05(\mathrm{D}+0,6 \cdot \mathrm{L}+\mathrm{E})$

$\mathrm{U}=0,9(\mathrm{D}+\mathrm{E})$

Dimana,

$\mathrm{D}=$ beban mati,

$\mathrm{L}=$ beban hidup,

$\mathrm{W}=$ beban angin, dan

$\mathrm{E} \quad=$ beban gempa. 


\section{e. Kuat Rencana}

Kuat rencana komponen struktur dan penampangnya, sehubungan dengan perilaku lentur, beban normal, geser, dan torsi, harus diambil sebagai hasil kali kuat nominal, yang dihitung berdasarkan ketentuan dan asumsi dari tata cara ini, dengan suatu faktor reduksi kekuatan $\varphi$. Faktor reduksi kekuatan $\varphi$ ditentukan sebagai berikut:

Momen lentur tanpa gaya aksial

$\varphi=0.90$ SNI 2847-2013 pasal 9.3.2.7

Gaya aksial tarik, atau momen dengan gaya tarik

$\varphi=0.90$ SNI 2847-2013 pasal 9.3.2.1

Gaya aksial tekan, atau momen dengan gaya tekan

$\varphi=0.75$ SNI 2847-2013 pasal 9.3.2.2

Gaya geser

$\varphi=0.75$ SNI 2847-2013 pasal 9.3.2.3

\section{METODE}

Metodologi penelitian merupakan tahap-tahap penelitian yang harus ditetapkan dahulu sebelum melakukan pemecahan masalah, sehingga penelitian dapat dilakukan dengan terarah dan memudahkan dalam menganalisis permasalahan yang ada. Berikut diagram alir Metode Penelitian yang digunakan dapat dilihat pada gambar 2 berikut :

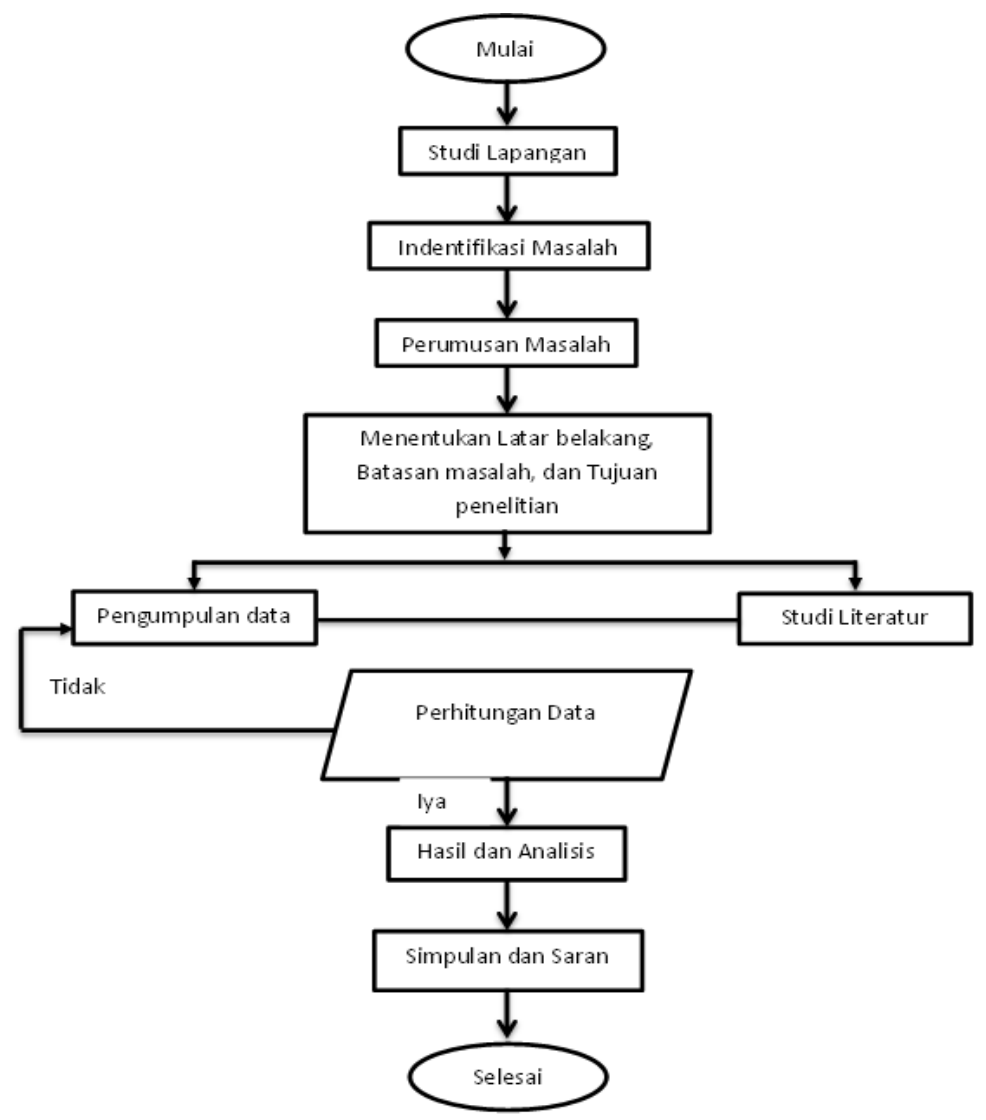

Gambar 1. Diagram Alir Proses Penelitian 


\section{Diagram Alir Perancangan}

Perancangan struktur merupakan suatu tahapan yang harus dilakukan sebelum berlangsungnya proses pembangunan dengan mengacu kepada peraturan - peraturan yang berkaitan dengan struktur bangunan gedung bertingkat supaya hasilnya sesuai yang diharapkan. Diagram alir menjelaskan secara detail mengenai perancangan struktur bangunan. Secara umum metode perancangan struktur gedung Sekolah SMK ALMurqoniyah dengan system rangka pemikul momen adalah sebagai berikut:

1. Pengumpulan Data

a. $\quad$ Buku - buku peraturan, antara lain : SNI 1726 - 2012 tentang Tata Cara Perencanaan Ketahanan Gempa Untuk Bangunan Gedung, SNI 2847-2013 tentang Tata Cara Perencanaan Struktur Beton Untuk Bangunan Gedung, dan SNI 03 - 1727 - 1989 tentang Tata Cara Pembebanan Indonesia Untuk Rumah dan Gedung.

b. Lokasi Bangunan

Bangunan SMK Al-Murqoniyah yang berlokasi di jl.tajur tapos RT 21/07 Kp. tajur tapos, Desa Hambalang, kec. Citeureup, Kab. Bogor.

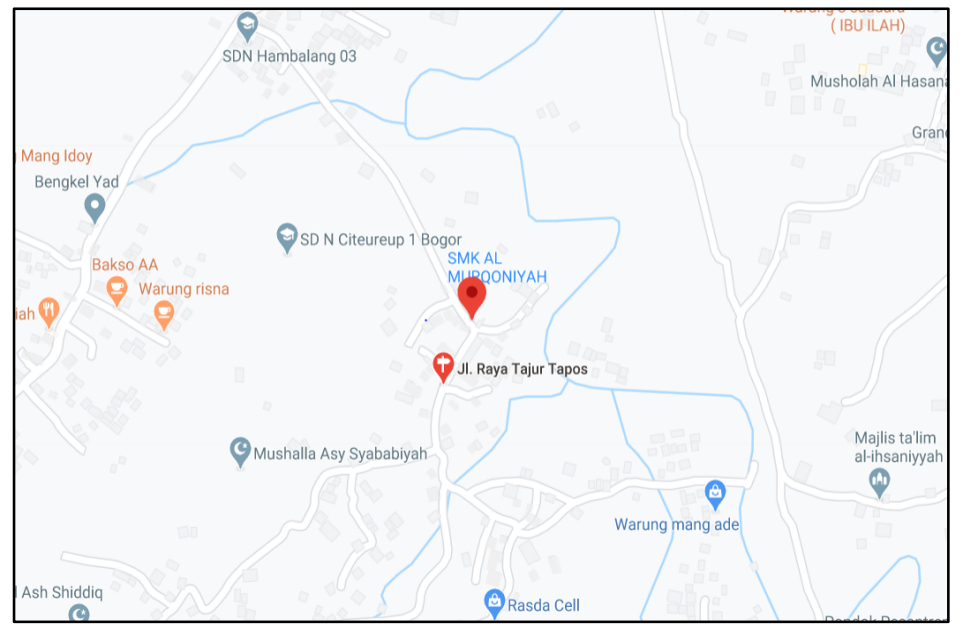

Gambar 2. Lokasi Bangunan SMK Al-Murqoniyah

2. Data Teknis Bangunan

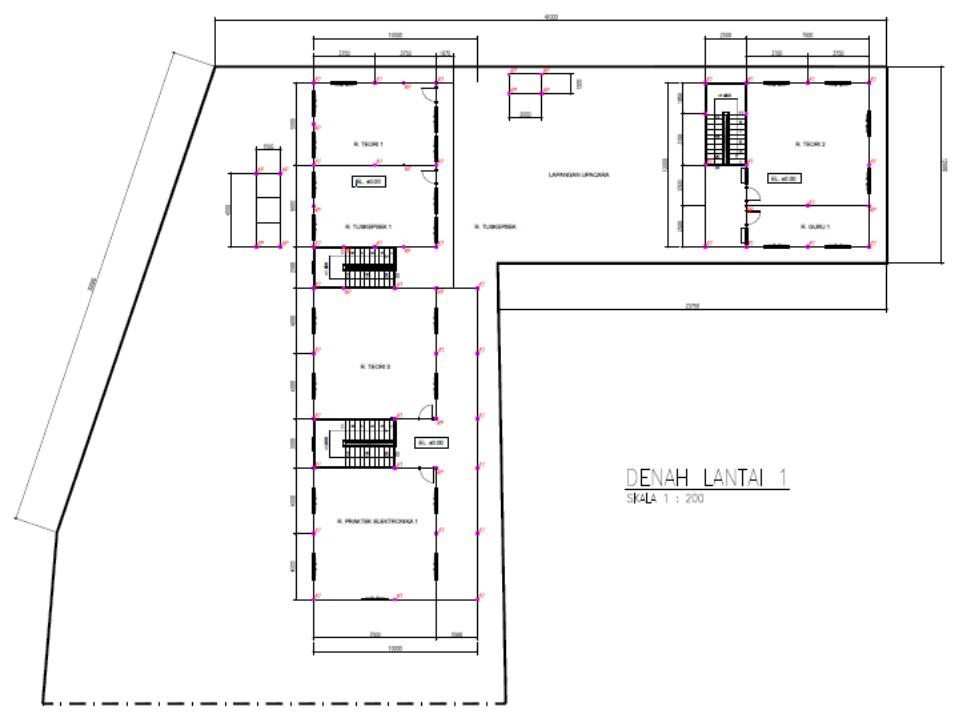

Gambar 3. Denah Bangunan SMK Al-Murqoniyah

$\begin{array}{ll}\text { Jumlah Lantai } & : 1 \text { Lantai Existing } \\ \text { Jenis Konstruksi } & : \text { Beton bertulang } \\ \text { Tahun Konstruksi } & :-\end{array}$


Jenis Pondasi

Ukuran Kolom

Ukuran Balok

Mutu Beton

Mutu Tulangan

Mutu Baja

Kondisi Tanah

\section{Standar / Peraturan}

a. American Concrete Institute (ACI 318-99)

b. SNI 2847-2013 Tata Cara Perencanaan Struktur Beton untuk Bangunan Gedung.

c. Peraturan Pembebanan Indonesia untuk Gedung (PPIUG)-1983

d. SNI 1726-2012 Tata Cara Perencanaan Perencanaan Gempa untuk BangunanGedung.

e. SNI 1729-2002 Tata Cara Perencanaan Struktur Baja untuk Bangunan Gedung.

\section{Program / Software}
a. ETABS Versi 18.0.0
b. PCACOL
c. Spreadsheet Excel

\section{HASIL DAN PEMBAHASAN}

\section{Penentuan Parameter Percepatan Spektral Desain}

Parameter respon spectra percepatan untuk gempa tertimbang maksimum yang telah disesuaikan dengan kelas dan koefisien situs adalah sebagai berikut:

$$
\begin{aligned}
S_{m s} & =F a \cdot S s \\
& =0,9 \cdot 1,0434 \\
& =0,93906 \\
& =F v \cdot S_{1} \\
& =2,4 \cdot 0,4762 \\
& =1,14288 \\
& =\frac{2}{3} \cdot S_{M S} \\
S_{D S} & =\frac{2}{3} \cdot 0,93906 \\
& =0,62604 \\
& =\frac{2}{3} \cdot 1,14288 \\
& =0,76192 \\
S_{D 1} &
\end{aligned}
$$

\section{Gaya Gempa Statuk Lateral Ekivalen}

Parameter perhitungan gempa statik adalah sebagai berikur:

$$
\begin{aligned}
\mathrm{T}_{\mathrm{a}} & =\mathrm{C}_{\mathrm{t}} \cdot \mathrm{h}_{\mathrm{n}}{ }^{\mathrm{x}} \\
& =0,0466 \cdot 8,6^{0,9} \\
& =0,32317 \\
\mathrm{~T} & =\mathrm{Cu} \cdot \mathrm{Ta} \\
& =1,4 \cdot 0,32317 \\
=0,45243 &
\end{aligned}
$$

Pada program ETABS didapatkan periode gedung untuk arah $\mathrm{x}$ dan y yaitu $\mathrm{Tx}=\mathrm{Ty}=1,12665$ detik, karena $\mathrm{Ta}<\mathrm{Tc}<\mathrm{Cu}$.Ta, maka periode gedung telah memenuhi syarat batas periode limit statik. 
Tabel 2. Hasil Perhitungan Analisis Statik

\begin{tabular}{|c|c|c|c|c|c|}
\hline Story & HI & $\mathbf{W i}$ & $\mathbf{K}$ & $\mathbf{W i H i}^{\wedge} \mathbf{k}$ & $\mathrm{Cv}$ \\
\hline & $\mathbf{M}$ & $\mathbf{K g}$ & & kgf-m & \\
\hline STORY2 & 8,6 & 11801,28 & 1,31 & 199171,64 & 0,75 \\
\hline STORY1 & 3,8 & 11238,29 & 1,31 & 64884,84 & 0,25 \\
\hline TOTAL & 12,4 & 23039,57 & 2,62664596 & 264056,4839 & 1 \\
\hline
\end{tabular}

\section{Geser Dasar Seismik}

$$
\begin{aligned}
& C_{s}=\frac{S_{D S}}{\left(\frac{R}{I_{e}}\right)} \\
&=\frac{0,62604}{\left(\frac{8}{1,5}\right)} \\
&=0,117383 \\
&<\frac{S_{D 1}}{\left(\frac{R}{I_{e}}\right)} \\
& C_{s} \quad \frac{0,76192}{1,126646\left(\frac{8}{1}\right)} \\
&<0,126801 \\
& \text { Cs } \quad>0,044 . S_{D S} I_{e} \\
& \quad>0,044.0,117383.1,5
\end{aligned}
$$

Berdasarkan nilai Cs di atas, maka dapat di ambil nilai Cs sebesar 0,051

$$
\begin{aligned}
\mathrm{V}_{(\mathrm{x}, \mathrm{y})} & =\mathrm{C}_{\mathrm{s}} . \mathrm{W}_{\mathrm{t}} \\
& =0,126801.23039,5699 . \\
& =2921,443889 \mathrm{~kg}
\end{aligned}
$$

Tabel 3 Hasil Perhitungan Gaya Geser Statik

\begin{tabular}{ccccc}
\hline Story & Fx & Vx & Fy & Vy \\
\hline & Kgf & Kgf & kgf & kgf \\
\hline STORY2 & 2203,58 & 2203,58 & 2203,576937 & 2203,576937 \\
\hline STORY1 & 717,87 & 2921,44 & 717,8669526 & 2921,443889 \\
\hline
\end{tabular}

\section{Analisis Dan Desain Kontrol Dengan Etabs 2013}

\section{Gaya Geser Dasar Nominal / Base Shear (V)}

Pada SNI Gempa 1726 - 2012 dijelaskan bahwa nilai akhir respon dinamik struktur gedung terhadap pembebanan gempa nominasi akibat pengaruh gempa rencana dalam suatu arah tertentu tidak boleh kurrang dari $85 \%$ nilai respons ragam yang pertama.

Tabel 4. Nilai Base Shear Nominal Statik

\begin{tabular}{lccc}
\hline & V rencana & V program & V desain \\
\cline { 2 - 4 } Base Shear & $\mathbf{N}$ & $\mathbf{N}$ & $\mathbf{N}$ \\
\hline Vx & 4206691 & 4206691 & 4206691 \\
\hline Vy & 4206691 & 4206691 & 4206691 \\
\hline \multicolumn{4}{c}{ Sumber: Hasil Perhitungan, 2014 }
\end{tabular}


$\mathrm{V}$ rencana $=$ Vprogram, maka desain diambil sama dengan Vrencana untuk dibandingkan dengan $\mathrm{V}$ dinamiknya

\section{Perancangan Struktur Pelat \\ Data Material}

Data-data perencanaan pelat yang direncanakan adalah sebagai berikut:

a. Mutu Bahan : Baja, fy $=390 \mathrm{MPa}$

b. Beton, $\mathrm{f}^{\prime} \mathrm{c}=18,675 \mathrm{MPa}$

c. Tebal Pelat Rencana : Lantai $\quad=120 \mathrm{~mm}$

d. Selimut Beton : $20 \mathrm{~mm}$

e. Tulangan Rencana : diameter $10 \mathrm{~mm}$

\section{Perencanaan Penulangan Lantai}

Untuk menentukan kebutuhan tulangan diperlukaan perencanaan dengan data-data sebagai berikut :

- Tebal pelat (h)

$=120 \mathrm{~mm}$

- Panjang (Ln)

$$
\begin{aligned}
& =5000-200=4800 \mathrm{~mm} \\
& =3000-200=2800 \mathrm{~mm} \\
& =4800 / 2800=1,714
\end{aligned}
$$

- Lebar (Sn)

$(\beta \leq 2$, tulangan 2 Arah)

- Tebal penutup (p)

$=20 \mathrm{~mm}$

- D. tulangan $(\phi p)$

$=10 \mathrm{~mm}$

- Tinggi efektif, $\mathrm{dx}$

$=120-20-1 / 2.10$

$=95 \mathrm{~mm}$

dy $\quad=h-p-\phi p x-1 / 2 . \phi p y$

$=120-20-10-5$

$=85 \mathrm{~mm}$

- Kuat tekan (fc') $\quad=18,675 \mathrm{MPa}$

- Kuat leleh (fy) $\quad=390 \mathrm{MPa}$

Dari data-data diatas didapatkan :

$$
\begin{aligned}
& \rho b=\frac{0,85 \cdot \beta_{1} \cdot f c^{\prime}}{f y} \cdot \frac{600}{600+f y} \\
&= \frac{0,85 \cdot 0,85 \cdot 30}{390} \cdot \frac{600}{600+390} \\
&= 0.020967657 \\
&= 0,75 \cdot \rho b \\
& \rho_{\max } \quad 0,75 \cdot 0.020967657 \\
&=0.015725743
\end{aligned}
$$

Berdasarkan SNI 2847:2013 pasal 7.12.2.1, Luasan tulangan susut dan suhu menyediakan paling sedikit memiliki rasio tulangan terhadap luas bruto penampang beton sebagai berikut, tetapi tidak kurang dari 0,0014:

a. Slab dengan batang tulangan mutu fy $=280 \mathrm{MPa}$ atau fy $=350 \mathrm{MPa}$ adalah 0,002

b. Slab dengan batang tulangan mutu fy $=420 \mathrm{MPa}$ adalah 0,0018 Untuk slab dengan batang tulangan mutu $240 \mathrm{MPa}, \rho=0,002$

c. Slab dengan batang tulangan mutu melebihi fy $=420 \mathrm{Mpa}$ yang diukur pada regangan leleh sebesar $0,35 \%$ adalah $0,0018 \times 420 /$ fy

$$
\begin{array}{cl}
\begin{array}{c}
\text { Contoh Perencanaan Tulangan Tumpuan Arah X (tiap } 1 \text { meter) } \\
\mathrm{b}
\end{array} & =1000 \mathrm{~mm} \\
\mathrm{dx} & =95 \mathrm{~mm} \\
\mathrm{Mu} & =8180000 \mathrm{Nmm} \\
\mathrm{Mn} & =\frac{\mathrm{Mu}}{\phi}
\end{array}
$$




$$
\begin{aligned}
& =\frac{9088888.89}{0,9} \\
& =9088888.889 \mathrm{Nmm} \\
& \mathrm{Rn}=\frac{\mathrm{Mn}}{\mathrm{b} \cdot \mathrm{dx}^{2}} \\
& =\frac{9088888.89}{1000.95^{2}} \\
& =1.007079101 \mathrm{~N} / \mathrm{mm}^{2} \\
& \mathrm{Md}=\frac{\mathrm{fy}}{0,85 \cdot \mathrm{fc}^{\prime}} \\
& =\frac{390 \quad=\frac{1}{0,85.18,675} \cdot\left[1-\sqrt{1-\frac{2 \cdot \mathrm{m} \cdot \mathrm{Rn}}{\mathrm{fy}}}\right]}{=24.56886369 \mathrm{MPa}} \\
& \rho \\
& =0.002669817
\end{aligned}
$$

Berdasarkan SNI 03-2842-2013

$$
\begin{array}{lll}
\rho & < & \rho_{\max } \\
0.002669817 & < & 0.015725743 \text { (Diperlukan tulangan tunggal) } \\
\rho & < & \rho_{\min } \\
0.002669817 & < & 0,0018 \text { (Dipakai } \rho=0.015725743 \text { ) }
\end{array}
$$

$\mathrm{As}_{\mathrm{perlu}} \quad=\rho . \mathrm{b} \cdot \mathrm{dx}$$$
=0.015725743 .1000 \mathrm{~mm} .95 \mathrm{~mm}
$$$$
=253.6325731 \mathrm{~mm}^{2}
$$

Luas tulangan

$$
\begin{aligned}
& =0,25 \times 3,14 \times 10^{2} \\
& =78,5 \mathrm{~mm}^{2}
\end{aligned}
$$

n

$$
\begin{aligned}
& =\frac{\text { As perlu }}{\text { Luas tulangan }} \\
& =\frac{253.6326}{78,5} \\
& =3,23 \text { buah }
\end{aligned}
$$

Sehingga diambil tulangan sebanyak 4 buah tulangan.

$$
\begin{aligned}
& \mathrm{S} \quad \leq \frac{0,25 \cdot \pi \cdot \mathrm{D}^{2} \mathrm{~b}}{\mathrm{As}_{\text {perlu }}} \\
& \leq \frac{0,25 \cdot 3,14 \cdot 10^{2} \cdot 1000}{253 \cdot 6326} \\
& \leq 309,502 \mathrm{~mm}
\end{aligned}
$$

Berdasarkan SNI 2847:2013 pasal 13.3.2, spasi tulangan pada penampang kritis tidak boleh melebihi dua kali tebal slab maka digunakan spasi $150 \mathrm{~mm}$.

As ada

$$
\begin{aligned}
& =\text { luas } \phi \text { tulangan. Jumlah tulangan } \\
& =\left(\frac{1}{4} \cdot \pi \cdot 10^{2}\right) \cdot 7 \\
& =549,5 \mathrm{~mm}^{2}
\end{aligned}
$$

Syarat Rasio Tulangan : 


$$
\begin{aligned}
\rho \quad & =\frac{\mathrm{As}}{\mathrm{b} \times \mathrm{d}} \\
& =\frac{549,5}{1000 \times 95} \\
& =0,00578 \quad(\rho \min <\rho<\rho \text { maks }) \\
\mathrm{S}_{\text {pasang }} & <\quad 2 \mathrm{t} \\
150 \mathrm{~mm} & <\quad 240 \mathrm{~mm}
\end{aligned}
$$

Cek kekuatan nominal penampang :

$a$

$$
\begin{aligned}
& =\frac{\text { As.fy }}{0,85 \cdot \mathrm{fcb}} \\
& =\frac{549,5 \times 390}{0,85 \times 18,675 \times 1000}
\end{aligned}
$$

$=13,5 \mathrm{~mm}$

Menentukan letak garis netral :

$$
\begin{aligned}
c \quad & =\frac{a}{\beta_{1}} \\
& =\frac{13,5}{0,85}
\end{aligned}
$$

$=15,88 \mathrm{~mm}$

Kontrol keserasian regangan:

$$
\begin{aligned}
\varepsilon_{s} & =\frac{d-c}{c} \cdot 0,003 \\
& =\frac{95-15,88}{15,88} \cdot 0.003 \\
& =0,0149 \\
\varepsilon_{y} & =\frac{f y}{E s} . \\
& =\frac{390}{200000} \\
& =0,00195
\end{aligned}
$$

Perhitungan diatas menghasilkan $\varepsilon_{\mathrm{s}} \geq \varepsilon_{y}$, maka tulangan baja sudah leleh sesuai dengan asumsi f ${ }_{\mathrm{s}}=$ fy $=$ 390 Mpa. Dengan demikian, besarnya kapasitas momen dapat ditentukan.

$$
\mathrm{Mn}=\text { As.fy }\left(\mathrm{d}-\frac{\mathrm{a}}{2}\right)=594,5 \times 390\left(95-\frac{13,5}{2}\right)=20461203,75 \mathrm{Nmm}
$$

$\mathrm{Mu} \quad=\phi . \mathrm{Mn}$

$$
\begin{aligned}
& =0,9.20461203,75 \\
& =18415083,38 \mathrm{Nmm}
\end{aligned}
$$

$\mathrm{Mu}$ perlu $\leq$ Mu kapasitas $=8180000 \mathrm{Nmm} \leq 18415083,38 \mathrm{Nmm} \quad \ldots$ OK

Maka dipakai tulangan D10 - 150 untuk penulangan pada arah X (tumpuan) dan penampang ini dapat digunakan.

\section{Hasil Perhitungan}

Berdasarkan hasil perhitungan tulangan rencana yang dipakai untuk pelat parkir, maka didapatkan tulangan yang dipakai. Hasil analisis penulangan pelat dapat dilihat pada tabel. 
Tabel 5 Hasil Perhitungan Jarak Antar Tulangan Pelat Parkir Lantai P2-

\begin{tabular}{lcccc}
\hline Tulangan & Arah & $\begin{array}{c}\text { Momen } \\
(\mathbf{N m m})\end{array}$ & $\begin{array}{c}\text { As } \\
\left(\mathbf{m m}^{\mathbf{2}}\right)\end{array}$ & Tulangan Terpasang \\
\hline \multirow{2}{*}{ Lapangan } & $\mathrm{X}$ & 5701000 & 549,5 & $\mathrm{D} 10-150$ \\
\cline { 2 - 5 } & $\mathrm{Y}$ & 3899000 & 549,5 & $\mathrm{D} 10-150$ \\
\hline \multirow{2}{*}{ Tumpuan } & $\mathrm{X}$ & 4042000 & 549,5 & $\mathrm{D} 10-150$ \\
\cline { 2 - 5 } & $\mathrm{Y}$ & 3290500 & 549,5 & $\mathrm{D} 10-150$ \\
\hline
\end{tabular}

\section{Hasil Perhitungan}

Berdasarkan hasil analisis dan perhitungan, diperoleh jumlah tulangan lentur balok sebagai berikut:

Tabel 6 Jumlah Tulangan Lentur Balok

\begin{tabular}{ccccc}
\hline Balok & $\begin{array}{c}\text { Tumpuan } \\
\text { Atas }\end{array}$ & $\begin{array}{c}\text { Tumpuan } \\
\text { Bawah }\end{array}$ & $\begin{array}{c}\text { Lapangan } \\
\text { Atas }\end{array}$ & $\begin{array}{c}\text { Lapangan } \\
\text { Bawah }\end{array}$ \\
\hline B200X400 & 3D13 & 3D13 & 3D13 & 3D13 \\
\hline
\end{tabular}

\section{Perencanaan Tulangan Geser Dengan Metode Momen Kapasitas}

Berdasarkan SNI 2847-2013 Pasal 21.6.2.2, geser rencana akibat gempa pada balok dihitung dengan mengasumsikan sendi plastis terbentuk di ujung-ujung balok dengan tegangan tulangan lentur balok mencapai 1,25 fy dan faktor reduksi kuat lentur $\phi=1$.

a. Kapasitas momen ujung-ujung balok bila struktur bergoyang ke kanan (Tumpuan Kiri).

As $\quad=398.00 \mathrm{~mm}^{2}$

$a_{p r} \quad=\frac{1,25 \cdot A s \cdot f y}{0,85 \cdot f c^{\prime} \cdot b}$

$=\frac{1,25.398 .390}{0,85.18,675.200}$

$=61.11$

$\mathrm{Mpri}^{+} \quad=1,25 . A s . f y\left(\mathrm{~d}-a_{p r} / 2\right)$

$=1,25.398 .13 .390(363,5-61,11 / 2)$

$=64598426.80 \mathrm{Nmm}$

As $\quad=398.00 \mathrm{~mm}^{2}$

$a_{p r} \quad=\frac{1,25 \cdot A s \cdot f y}{0,85 \cdot f c^{\prime} \cdot b}$

$=\frac{1,25.398 .390}{0,85.18,675.200}$

$=61.11$

$\mathrm{Mpri}^{+} \quad=1,25 . A s \cdot f y\left(\mathrm{~d}-a_{p r} / 2\right)$

$=1,25.398 .13 .390(363,5-61,11 / 2)$

$=64598426.80 \mathrm{Nmm}$

b. Kapasitas momen ujung-ujung balok bila struktur bergoyang ke kiri (Tumpuan Kanan).

As $\quad=398.00 \mathrm{~mm}^{2}$

$a_{p r} \quad=\frac{1,25 \cdot A s \cdot f y}{0,85 \cdot f c^{\prime} \cdot b}$

$=\frac{1,25.398 .390}{0,85.18,675.200}$

$=61.11$

$\mathrm{Mpri}^{+} \quad=1,25$. As.fy $\left(\mathrm{d}-a_{p r} / 2\right)$

$=1,25.398 .13 .390(363,5-61,11 / 2)$

$=64598426.80 \mathrm{Nmm}$ 


$$
\begin{array}{ll}
\text { As } & =398 \cdot 00 \mathrm{~mm}^{2} \\
a_{p r} & =\frac{1,25 \cdot A s \cdot f y}{0,85 \cdot f c^{\prime} \cdot b} \\
& =\frac{1,25 \cdot 398 \cdot 390}{0,85 \cdot 18,675 \cdot 200} \\
& =61.11 \\
& =1,25 \cdot A s \cdot f y\left(\mathrm{~d}-a_{p r} / 2\right) \\
\text { Mpri }^{+} & =1,25 \cdot 398 \cdot 13.390(363,5-61,11 / 2) \\
& =64598426.80 \mathrm{Nmm}
\end{array}
$$

c. Diagram gaya geser. Reaksi geser di ujung kanan dan kiri balok akibat gaya gravitasi yang bekerja pada struktur. Hasil analisis struktur dengan program ETABS 2013.

Kombinasi beban gravitasi: $\quad \mathrm{Wu}=1,2 \mathrm{DL}+1,0 \mathrm{LL}$

$$
\begin{aligned}
\text { Didapat } \quad \mathrm{V}_{\mathrm{g}, \mathrm{ki}}= & \frac{W_{u \cdot} L_{n}}{2}=9291.00 \mathrm{~N} \\
\mathrm{~V}_{\mathrm{eb}, \mathrm{ka}}= & \frac{W_{u \cdot} L_{n}}{2}=9291.00 \mathrm{~N}
\end{aligned}
$$

d. Struktur bergoyang ke kanan.

$$
V e=\frac{{M_{p r_{1}}{ }^{+}+M_{p r_{3}}{ }^{-}}_{L n}}{L n}
$$

Total reaksi geser diujung kiri balok $\quad=30045.78+9291.00$

$$
=39336.78 \mathrm{~N}
$$

Total reaksi geser diujung kanan balok $=30045.78-9291.00$

Struktur bergoyang ke kiri.

$$
=20754.78 \mathrm{~N}
$$

$$
V e=\frac{M_{p r_{2}}{ }^{+}+M_{p r_{j 4}}{ }^{-}}{L n}
$$

Total reaksi geser diujung kiri balok

$$
\begin{aligned}
& =30045.78 \mathrm{~N} \\
& =30045.78+9291.00 \\
& =39336.78 \mathrm{~N}
\end{aligned}
$$

Total reaksi geser diujung kanan balok $=30045.78-9291.00$

$$
=20754.78 \mathrm{~N}
$$

e. Sengkang untuk gaya geser. SNI 03-2847-2012 Pasal 23.3.4(2): Vc $=0$ pada perencanaan geser di daerah sendi plastis apabila:

Gaya geser Ve akibat sendi plastis di ujung-ujung balok melebihi 1/2 (atau lebih) kuat geser perlu maksimum, $\mathrm{Vu}$, di sepanjang bentang,

$$
\begin{aligned}
& \text { Vu maks } \quad=12425.62 \mathrm{~N} \\
& V_{S}=\frac{V_{u}}{\phi}-V_{C}=V_{S}=\frac{12425.62}{0,75}-0=16567.49 \mathrm{~N}
\end{aligned}
$$

Maksimum $\mathrm{V}_{\mathrm{s}}$ :

$$
V_{s, \text { maks }}=\frac{2 \sqrt{f c^{\prime}}}{3} b_{w .} d=\frac{2 \sqrt{30}}{3} 200.363,5 \quad=209446,66 \mathrm{~N}
$$

Diameter tulangan sengkang D10 dengan 2 kaki $\left(\mathrm{A}_{\mathrm{V}}=157 \mathrm{~mm}^{2}\right)$

$$
\begin{array}{ll}
A v=0,25 \cdot 3,14 \cdot 10^{2} 2 & =157 \mathrm{~mm}^{2} \\
s=\frac{A v \cdot f y \cdot d}{V S}=\frac{157 \cdot 390 \cdot 363,5}{209446,66} & =106,266 \mathrm{~mm}
\end{array}
$$


Digunakan baja tulangan D10 dengan spasi tulangan $100 \mathrm{~mm}$

$$
V s=\frac{A v \cdot f y \cdot d}{s} \quad=\frac{157.390 .363,5}{100} \quad=222571,05 \mathrm{~N}
$$

SNI 2847-2013 Pasal 21.5.3(2): Spasi maksimum di sepanjang balok tidak boleh melebihi:

$1 \mathrm{~d} / 4$

2 6.D longitudinal bar diameter

$3 \quad 150 \mathrm{~mm}$

Dengan demikian digunakan sengkang 2 kaki D10 dipasang dengan spasi $10 \mathrm{~mm}$ di daerah sepanjang $2 \mathrm{~h}$ $(=800 \mathrm{~mm})$

Sengkang di daerah luar sendi plastis

$$
\begin{aligned}
& V_{c}=\frac{\sqrt{f c^{\prime}}}{6} b_{w .} d=\frac{1 \sqrt{18,675}}{6} 200363,5 \quad=52361,67 \mathrm{~N} \\
& V_{S}=\frac{V_{u}}{\phi}-V_{c} \quad=\frac{39336.78}{0,75}-52361,67 \quad=87,37 \mathrm{~N}
\end{aligned}
$$

Diameter tulangan sengkang D10 dengan 2 kaki $\left(A_{V}=157 \mathrm{~mm}^{2}\right)$

$$
\begin{array}{lr}
A v=0,25 \cdot 3,14 \cdot 10^{2} 2 & =157 \mathrm{~mm}^{2} \\
s=\frac{A v \cdot f y \cdot d}{V S}=\frac{157 \cdot 390 \cdot 363,5}{87,37} & =493,79 \mathrm{~mm}
\end{array}
$$

Digunakan baja tulangan D10 dengan spasi tulangan $150 \mathrm{~mm}$

\section{Perancangan Struktur Kolom \\ Perencanaan Tulangan Lentur Kolom \\ Metode Diagram Interaksi}

Perencanaan tulangan lentur dengan metode diagram interaksi menggunakan program pcaCOL untuk membuat diagram interaksi.

Tabel 7. Nilai Diagram Interaksi Kolom 200x250 Dari ETABS

\begin{tabular}{cccccccc}
\hline Story & Column & Load & P & V2 & V3 & M2 & M3 \\
\hline STORY2 & C26 & COMB4 & 279,04 & $-17,09$ & 4,41 & 8,359 & $-32,259$ \\
\hline STORY2 & C26 & COMB3 & 283,10 & $-17,08$ & $-4,45$ & $-8,457$ & $-32,227$ \\
\hline STORY1 & C26 & COMB2 & 527,06 & $-5,03$ & $-0,06$ & 0,016 & $-1,624$ \\
\hline STORY1 & C26 & COMB2 & 526,63 & $-5,03$ & $-0,06$ & 0,035 & $-0,115$ \\
\hline
\end{tabular}

Tabel 8. Nilai Diagram Interaksi Kolom 150x150 Dari ETABS

\begin{tabular}{cccccccc}
\hline Story & Column & Load & P & V2 & V3 & M2 & M3 \\
\hline STORY2 & C43 & COMB12 & 20,540 & $-3,22$ & 1,05 & 1,997 & $-6,095$ \\
\hline STORY2 & C43 & COMB4 & 37,650 & $-3,22$ & 1,11 & 2,108 & $-6,091$ \\
\hline STORY1 & C35 & COMB8 & 145,58 & 1,08 & $-3,51$ & $-2,314$ & 0,622 \\
\hline STORY1 & C35 & COMB8 & 145,33 & 1,08 & $-3,51$ & $-1,086$ & 0,242 \\
\hline
\end{tabular}

Dari hasil analisa program, diketahui Gaya Aksial (P) dan Momen yang bekerja pada kolom serta dapat digambarkan diagram interaksi sebagai berikut: 


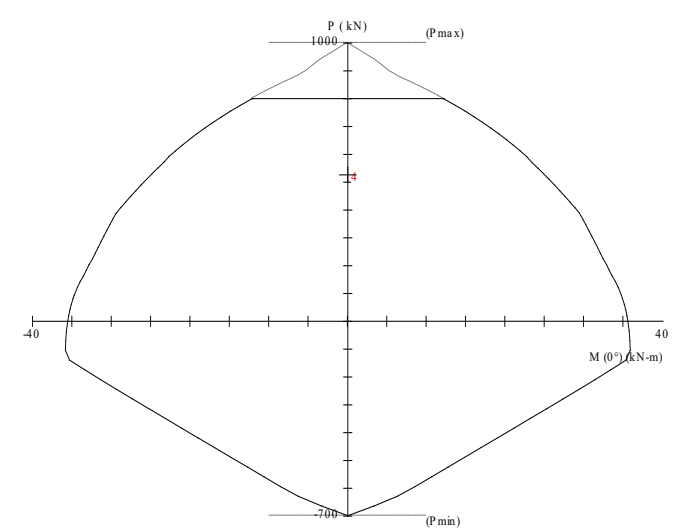

Gambar 4. Diagram Interaksi Kolom 200x250

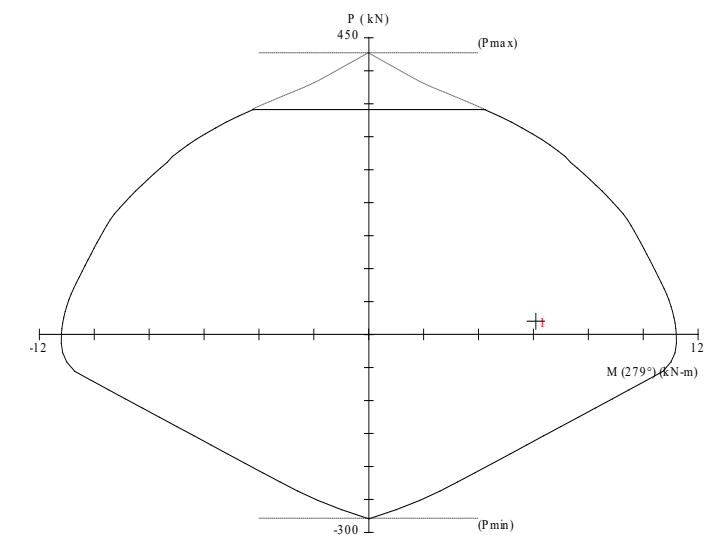

Gambar 5. Diagram Interaksi Kolom 150x150

Dari hasil diagram interaksi didapatkan jumlah tulangan sesuai gambar dibawah ini:

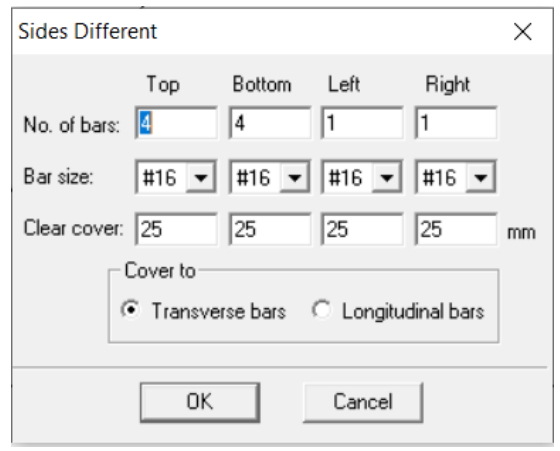

Gambar 6. Kolom 200x250 Dipasang tulangan 10D16

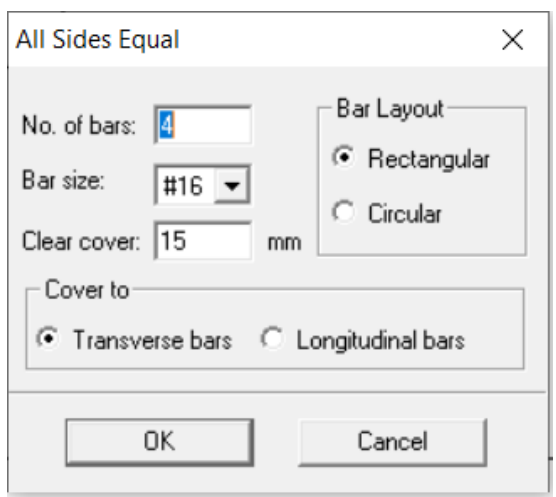

Gambar 7. Kolom 150x150 Dipasang tulangan 4D16 


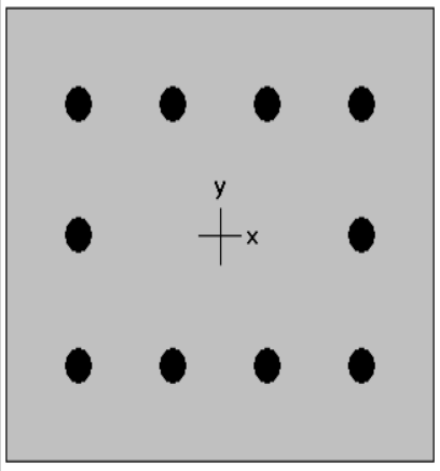

Gambar 8. a (4D16150X150)

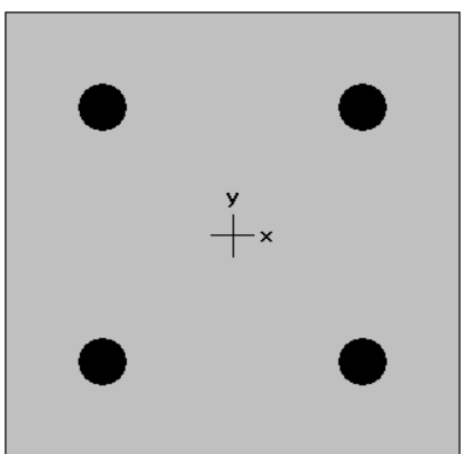

b. (10D16 K200X250)

\title{
5. KESIMPLAN DAN SARAN
}

\begin{abstract}
Kesimpulan
Berdasarkan hasil analisis dan perhitungan yang telah dilakukan pada perencanaan ulang (redesign) pembangunan ruang belajar SMK Al- Murqoniyah, Hambalang dapat disimpulkan bahwa jumlah tulangan yang didapatkan dari hasil analisis untuk tulangan pelat $(\mathrm{t}=120 \mathrm{~mm})$ digunakan tulangan $\mathrm{D} 10-100$ untuk masing-masing tumpuan dan lapangan, pada struktur balok (200X400 mm) digunakan tulangan lentur 3D13 pada daerah tekan dan 3D13 pada daerah tarik, dengan jarak sengkang pada tumpuan adalah D10-100 pada daerah tumpuan dan D10-150 pada daerah lapangan, serta untuk tulangan lentur kolom (200X250 mm) digunakan tulangan 10D16 dan tulangan sengkang D10-100 pada daerah tumpuan dan tulangan D10-150 pada daerah lapangan. Berdasarkan hasil analisis yang telah dilakukan menggunakan bantuan program analisis struktur, dapat dinyatakan bahwa elemen struktur gedung ini aman secara analisis dan struktur gedung belajar SMK Al- Murqoniyah telah direncanakan sesuai kaidah perancangan yang berlaku, yaitu yang di atur dalam SNI 1726 - 2012 tentang Tata Cara Perencanaan Ketahanan Gempa Untuk Bangunan Gedung dan SNI 2847 2013 tentang Tata Cara Perencanaan Struktur Beton Untuk Bangunan Gedung.
\end{abstract}

\section{Saran}

Berdasarkan analisis yang telah dilakukan, perlu adanya perbaikan - perbaikan melalui beberapa saran sebagai berikut Perlu adanya perhitugan terhadap analisis struktur bawah yaitu pondasi. Hal ini dikarenakan kondisi pandemi Covid-19 membuat pelaksanaan tidak berjlalan dengan baik sehingga mengakibatkan tidak tersedia nya data tanah dalam megolah data dan melakukan analisis, perlu adanya peninjauan lebih lanjut mengenai perencanaan pondasi yaitu dengan melakukan penyelidikan tanah di lokasi.

\section{REFERENCES}

Badan Standar Nasional. 2013. Tata Cara Perhitungan Struktur Beton Untuk Bangunan Gedung. SNI 28472013.

Badan Standar Nasional. 2012. Tata Cara Perencanaan Ketahanan Gempa Untuk Bangunan Gedung. SNI $1726-2012$.

Departemen Pekerjaan Umum. 1983. Peraturan Pembebanan Indonesia Untuk Gedung., Bandung : Direktorat Penyelidikan Masalah Bangunan.

Departemen Pekerjaan Umum. 1989. Tata Cara Pembebanan Indonesia Untuk Rumah dan Gedung. SNI 03 $1727-1989$.

Nawy, Edward G. 1990. Beton Bertulang Suatu Pendekatan Dasar. Bandung : Penerbit PT. Eresco.

Ramadhan, Punto Ajie. 2013. Perencanaan Struktur Gedung Bertingkat 12 Lantai Pada Zona Gempa Khusus dengan Metode Sistem Ganda (Dual System). Program Sarjana. Universitas Gunadarma. Depok.

Kabdiyono, Era Agita. 2014. Perancangan Struktur Balok, Kolom Dan Beam Column Joint Gedung Parkir 12 Lantai Dengan Metode Sistem Rangka Pemikul Momen Khusus Program Sarjana. Universitas Gunadarma. Depok.

Asroni, Ali, 2010. Balok Beton Bertulang, Edisi Pertama, Graha Ilmu, Surakarta. 